\title{
VARIASI MORFOMETRI DAN KARAKTER MORFOLOGI KEONG MAS (Pomacea canaliculata) PADA SAWAH DI DESA ABIANSEMAL BADUNG-BALI
}

\section{VARIATION MORPHOMETRY AND MORPHOLOGICAL CHARACTER OF GOLDEN APPLE SNAIL (Pomacea canaliculata) IN RICE FIELD ABIANSEMAL VILLAGE, BADUNG}

\author{
I Gede Agus Suarmustika, Ni Made Suartini, Job Nico Subagio \\ Program Studi Biologi, Fakultas Matematika dan Ilmu Pengetahuan Alam, Universitas Udayana \\ Email: agussuarmustika@gmail.com
}

\section{INTISARI}

Tujuan penelitian ini adalah untuk mengetahui variasi morfologi dan karakter morfologikeong mas ( $P$. canaliculata) pada sawah-sawah di Desa Abiansemal. Keong mas dapat ditemukan hidup di air tawar antara lain danau, sungai, selokan kecil dan juga di area persawahan. Habitat persawahan di Bali masih dapat dijumpai di desa Abiansemal, kabupaten Badung tetapi informasi mengenai keong mas yang ada di habitat persawahan tersebut belum banyak diungkap terutama jenis keong mas $(P$. canaliculata). Oleh karena itu, perlu dilakukan penelitian mengenai keong mas yang ada di Desa Abiansemal. Penelitian ini dilakukan di sawah yang terdapat di Desa Abiansemal, Kecamatan Abiansemal, Kabupaten Badung, Provinsi Bali. Penelitian dilakukan dari bulan April-Mei 2017. Pengambilan sampel keong mas ( $P$. canaliculata) dilakukan pada tiga petak sawah di tiga banjar di Desa Abiansemal yaitu di banjar Latu Sari, banjar Aseman, dan banjar Juwet. Sawah dipilih secara acak kemudian pada tiap petak sawah terpilih diambil sampel keong mas dengan menggunakan kuadrat $1 \times 1 \mathrm{~m}$. Sampel pada tiap petak sawah diambil sebanyak tiga kali ulangan. Semua sampel keong mas yang terdapat di dalam kuadrat diambil dan dibersihkan kemudian diawetkan dengan alkohol 70\%. Sampel keong mas yang diperoleh dihitung kepadatannya dan semua karakter morfologi dan morfometri dianalisis secara deskriptif. Pada penelitian ini ditemukan bahwa pada morfologi keong mas berpola garis untuk karakter morfometri, tinggi cangkang lebih tinggi di daerah banjar Juwet, Untuk lebar mulut cangkang lebih besar di daerah banjar Aseman dan tinggi tutup cangkang lebih tinggi di daerah banjar Latu Sari, sedangkan morfologi berpola polos untuk karakter morfometri, tinggi cangkang dan tinggi sulur lebih tinggi di daerah banjar Latu Sari, dan untuk tinggi dan lebar tutup cangkang lebih tinggi dan lebih lebar di daerah banjar Aseman, sedangkan untuk karakter morfometri yang lainnya hasil yang ditemukan hampir sama.

\section{Kata kunci: keong mas, sawah, morfologi, morfometri}

\section{ABSTRACT}

The purpose of this study was to determine variations in morphology and morphological characteristics of golden apple snails ( $P$. canaliculata) in rice fields in Abiansemal Village. Gold apple snails can be found living in fresh water, including lakes, rivers, small ditches and also in rice fields. Rice field habitats in Bali can still be found in Abiansemal village, Badung regency, but not much information has been disclosed about the snails in the rice field habitat, especially the golden apple snail species ( $P$. canaliculata). Therefore, it is necessary to do research on the golden apple snails in Abiansemal Village. This research was carried out in rice fields located in Abiansemal Village, Abiansemal District, Badung Regency, Bali Province. The study was conducted from April to May 2017. Sampling of golden apple snail (P. canaliculata) was carried out in three plots of rice fields in three banjars in Abiansemal Village, namely in the Latu Sari, Banjar Aseman, and Juwet banjars. The rice field was chosen randomly and then in each selected field of rice the golden apple snail sample was taken using a 1x1m square. Samples on each plot of rice were taken three times. All samples of golden snail contained in the squared were taken and cleaned and then preserved with $70 \%$ alcohol. The golden apple snail sample obtained was calculated for its density and all morphological and morphometric characters were analyzed descriptively. In this study it was found that the morphology of golden apple snail patterned lines for morphometric characters, the shell height was higher in the banjar Juwet area, for the width of the shell mouth was greater in the banjar area Aseman and the height of the shell cover was higher in the banjar area of Latu Sari, while the morphology was plain patterned for morphometric characters, the height of the shell and the height of tendrils were higher in the banjar area of Latu Sari, and for the height and width of the cover the shell was higher and wider in the banjar area of Aseman, while for the other morphometric characters the results were found almost the same.

\section{Keywords: snail, rice field, morphology, morphometry}

\section{PENDAHULUAN}

Indonesia memiliki jumlah jenis Mollusca terbanyak di wilayah Indo-pasifik. Para ahli juga memperkirakan bahwa setidaknya $20 \%$ dari \pm 100.000 jenis Mollusca yang masih hidup hingga sekarang ditemukan di Indonesia (Dharma, 1992). Mollusca merupakan filum terbesar kedua dalam kerajaan hewan setelah filum Arthropoda. Kelas Gastropoda merupakan kelas terbesar dari Filum Mollusca, terdiri atas kurang lebih 80.000 jenis dimana sekitar 1.500 jenis diantaranya terdapat di Indonesia dan sekitarnya. (Nontji, 2002). Lebih lanjut disebutkan bahwa kelas Gastropoda memiliki keanekaragaman habitat yang sangat luas. Ditemukannya Gastropoda di berbagai macam habitat menunjukkan bahwa Gastropoda merupakan kelas yang paling sukses di antara kelas yang lain. Gastropoda dapat ditemukan di darat, laut dan air tawar. Gastropoda yang hidup di air tawar bisa menempati habitat danau, sungai, selokan kecil dan juga habitat sawah.

Gastropoda yang hidup di sawah, salah satunya adalah keong mas Pomacea canaliculata (Dharma 1992). Keong mas dapat dikonsumsi dan dapat diolah menjadi ZPT (Zat Perangsang Tumbuh) organik (Ameliawati, 2013) sedangkan kerugian yang diakibatkannya yaitu dapat menimbulkan kerusakan hingga 10-40\% dari keseluruhan areal pertanaman padi di Indonesia yakni di Jawa, Sumatra, Kalimantan, NTB dan Bali (Budiyono, 2006). Mengacu pada Direktorat Perlindungan Tanaman Pangan (2008), dinyatakan bahwa pada habitat sawah, perkembangan keong mas meningkat relatif cepat sehingga cepat juga merusak tanaman padi. Berdasarkan hasil penelitian (Wiresyamsi dan Haryanto, 2008), besarnya intensitas serangan hama keong mas mempengaruhi jumlah rumpun tanaman padi.

Keong mas di beberapa negara Asia Tenggara berasal dari beberapa daerah di Amerika selatan termasuk Argentina (Cowie et al, 2006). Suharto et al. (2006) menyatakan bahwa keong mas yang masuk ke Indonesia diduga ada 3 jenis, yakni $P$. canaliculata, $P$. paludosa dan $P$. insularum. DiIndonesia ditemukan banyak variasi bentuk cangkang keong mas ini, pada umumnya semua disebut keong $P$. canaliculata. Menurut Marwoto dan Isnaningsih (2011), terdapat variasi morfologi $P$. canaliculata yang diamati dari koleksi Museum Zoologi Bogor, dimana sampel $P$. canaliculata tersebut berasal dari beberapa daerah di Indonesia diantaranya yaitu Bengkulu, Palu, Madiun, Bone, Bantimurung dan Danau Maninjau. 


\section{$\cap \leadsto \mid \begin{aligned} & \text { DIRECTORY OF } \\ & \text { OPEN ACCESS } \\ & \text { JOURNALS }\end{aligned}$}

Habitat persawahan di Bali masih dapat dijumpai di desa Abiansemal, kabupaten Badung tetapi informasi mengenai keong mas terutama mengenai variasi morfologi keong mas yang ada di habitat persawahan tersebut belum banyak diungkap. Oleh karena itu, perlu dilakukan penelitian mengenai keanekaragaman Gastropoda sawah yang dalam penelitian ini akan difokuskan di sawah yang ada di desa Abiansemal.

\section{MATERI DAN METODE}

\section{Tempat dan Waktu Penelitian}

Pengambilan sampel keong mas dilakukan pada sawahsawah yang terdapat di beberapa banjar di Desa Abiansemal, Kecamatan Abiansemal, Kabupaten Badung, Provinsi Bali. Pengamatan karakter morfologi dan morfometri sampel keong mas yang diperoleh dilakukan di Laboratorium Taksonomi Hewan Program Sudi Biologi Fakultas Matematika dan Ilmu Pengetahuan Alam Universitas Udayana. Penelitian dilakukan dari bulan April-Juni 2017.

\section{Pengambilan sampel Keong Mas.}

Pengambilan sampel keong mas dilakukan pada tiga petak sawah di tiga banjar di Desa Abiansemal yaitu di banjar Latu Sari, banjar Aseman, dan banjar Juwet. Sawah dipilih secara acak kemudian pada tiap petak sawah terpilih diambil sampel keong mas dengan menggunakan kuadrat dari kayu yang berukuran $1 \times 1 \mathrm{~m}$. Sampel pada tiap petak sawah diambil sebanyak tiga kali ulangan. Semua sampel keong mas yang terdapat di dalam kuadrat diambil dan dibersihkan kemudian diawetkan dengan alkohol 70\%. Pada saat pengambilan sampel keong mas, juga dilakukan pengukuran beberapa faktor lingkungan diantaranya adalah suhu air dengan menggunakan termometer batang, ketinggian air di sawah tempat pengambilan sampel keong mas menggunakan penggaris serta tekstur substrat diamati secara visual.

\section{Pengamatan Sampel Keong Mas}

Pengamatan sampel yang diperoleh dilakukan dengan mengamati semua karakter morfologi cangkang diantaranya bentuk cangkang, pola warna cangkang, ornament cangkang, tinggi dan lebar cangkang, tinggi dan lebar tutup cangkang, tinggi dan lebar mulut cangkang, tinggi sulur, jumlah putaran cangkang, tipe putaran cangkang. Pengamatan semua karakter morfometri keong mas menggunakan jangka sorong mengacu pada Isnaningsih dan Marwoto (2011) serta Ramakrisna et al. (2014)

Analisis data

Jumlah individu keong mas $(P$. canaliculata) yang diperoleh kemudian dihitung kepadatannya dengan rumus:

$$
\begin{aligned}
& \mathrm{K}=\frac{\mathrm{Ni}}{\mathrm{A}} \\
& \mathrm{K}=\text { kepadatan individu (ind } / \mathrm{m}^{2} \text { ) } \\
& \mathrm{Ni}=\text { jumlah individu } \\
& \mathrm{A}=\text { luas kuadrat }
\end{aligned}
$$

\section{HASIL}

Berdasarkan hasil yang diperoleh dari pengamatan karakter morfologi dan morfometri dari semua lokasi pengambilan sampel maka ditemukan dua variasi cangkang. Variasi cangkang yang ditemukan adalah cangkang dengan pola garis dan cangkang polos (Gambar 1).

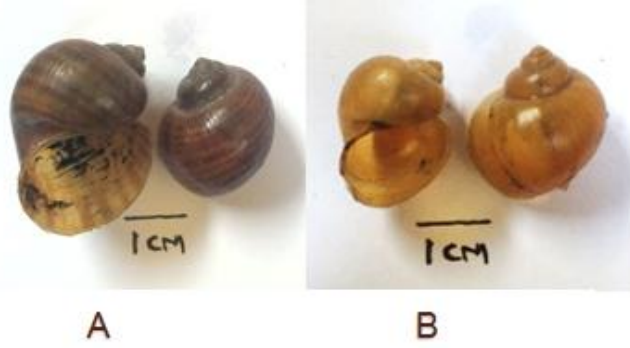

Gambar 1. Morfologi cangkang keong mas (A) cangkang pola garis, (B) cangkang polos.

\section{Morfometri keong mas dengan cangkang pola garis}

Cangkang membulat, warna coklat cerah pada bibir cangkang dan terdapat garis melintang berwarna coklat tua hingga tepi mulut cangkang. Cangkang berputar ke kanan (dextral). Tinggi cangkang1,53-3,27cm, lebar cangkang 1,12 $-3,29 \mathrm{~cm}$, tinggi body whorl $1.17-2.83 \mathrm{~cm}$, tinggi sulur $0.43-$ $0.96 \mathrm{~cm}$, tinggi mulut cangkang (aperture) $1,12-1,86 \mathrm{~cm}$, lebar mulut cangkang (aperture) 0,65 - 2,93cm, tinggi tutup cangkang 0,37 -1,94 cm, lebar tutup cangkang $0,65-1,64 \mathrm{~cm}$.

Tabel 1. Hasil pengukuran rata-rata karakter morfometri cangkang keong mas pola garis $(\mathrm{cm})$

\begin{tabular}{llcccccc}
\hline N Karakter & \multicolumn{7}{c}{ Banjar } \\
\cline { 3 - 8 } & \multicolumn{2}{l}{ Latu Sari } & \multicolumn{3}{c}{ Aseman } & Juwet \\
& & & & & & \\
\hline 1 & Tinggi cangkang & 2.52 & \pm 0.266 & 2.46 & \pm 0.263 & 2.45 & \pm 0.223 \\
2 & Lebar cangkang & 1.78 & \pm 0.533 & 1.56 & \pm 0.317 & 1.47 & \pm 0.373 \\
3 & Tinggi body whorl & 1.76 & \pm 0.317 & 1.73 & \pm 0.394 & 1.64 & \pm 0.352 \\
4 & Tinggi sulur & 0.70 & \pm 0.153 & 0.66 & \pm 0.181 & 0.58 & \pm 0.118 \\
5 & Tinggimulutcangkang & 1.54 & \pm 0.228 & 1.55 & \pm 0.236 & 1.51 & \pm 0.229 \\
6 & Lebarmulutcangkang & 1.21 & \pm 0.217 & 1.21 & \pm 0.207 & 1.19 & \pm 0.252 \\
7 & Tinggi tutupcangkang & 0.69 & \pm 0.769 & 0.99 & \pm 0.669 & 0.92 & \pm 0.629 \\
8 & Lebartutupcangkang & 0.57 & \pm 0.638 & 0.85 & \pm 0.564 & 0.80 & \pm 0.562 \\
\hline
\end{tabular}

\section{Morfometri keong mas dengan cangkang polos}

Cangkang membulat, cangkang polos warna kuning keemasan pada seluruh bagian cangkang (dari bibir cangkang ke arah sulur). Cangkang berputar ke kanan (dextral). Tinggi cangkang 1,53-3,36cm, lebar cangkang 0,14-3,41 cm, tinggi body whorl $1,22-2,73 \mathrm{~cm}$, tinggi sulur $0,43-1,24 \mathrm{~cm}$, tinggi mulut cangkang (aperture)0,64-2,22cm, lebar mulut cangkang (aperture)0,15- 1,57cm, tinggi tutup cangkang $0,72-2,14 \mathrm{~cm}$, lebar tutup cangkang $0,14-1,74 \mathrm{~cm}$.

Tabel 2. Hasil pengukuran rata - rata karakter morfometri cangkang keong mas pola polos $(\mathrm{cm})$

\begin{tabular}{lllllll}
\hline N Karakter & \multicolumn{7}{c}{ Banjar } \\
\cline { 2 - 7 } & \multicolumn{1}{l}{ Latu Sari } & Aseman & Juwet \\
& & & & & & \\
\hline 1 Tinggi cangkang & 2.48 & \pm 0.302 & 2.47 & \pm 0.344 & 3.02 & \pm 3.50 \\
2 Lebar cangkang & 1.73 & \pm 0.527 & 1.55 & \pm 0.376 & 1.63 & \pm 0.36 \\
3 Tinggi body whorl & 1.72 & \pm 0.335 & 1.65 & \pm 0.331 & 1.66 & \pm 0.32 \\
4 Tinggi sulur & 1.01 & \pm 4.429 & 0.62 & \pm 0.202 & 0.66 & \pm 0.20 \\
5 Tinggi mulutcangkang & 1.55 & \pm 0.247 & 1.55 & \pm 0.232 & 1.52 & \pm 0.18 \\
6 Lebarmulutcangkang & 1.24 & \pm 0.224 & 2.93 & \pm 15.08 & 1.21 & \pm 0.18 \\
7 Tinggi tutupcangkang & 1.94 & \pm 15.20 & 0.83 & \pm 0.689 & 0.95 & \pm 0.65 \\
8 Lebartutupcangkang & 0.61 & \pm 0.606 & 0.73 & \pm 0.594 & 0.84 & \pm 0.57 \\
\hline
\end{tabular}

Berdasarkan hasil pengukuran beberapa karakter tersebut maka hubungan antar karakter dianalisis regresi yaitu antara tinggi dan lebar cangkang serta tinggi dan lebar mulut cangkang (aperture). Seperti tercantum pada Gambar 2 dan 3. 


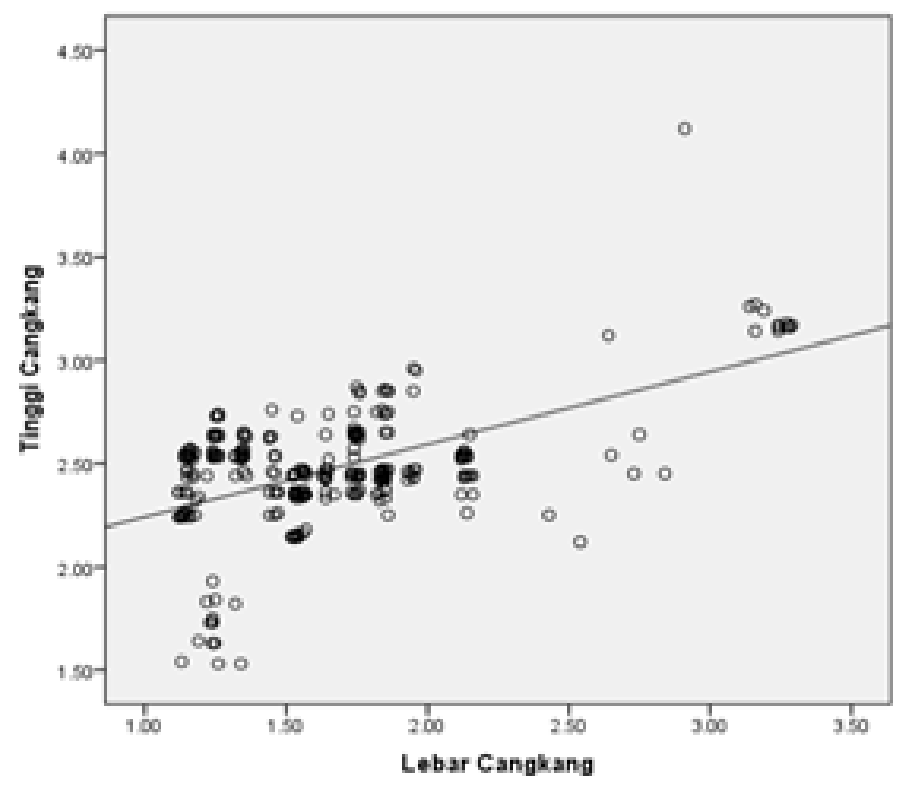

A

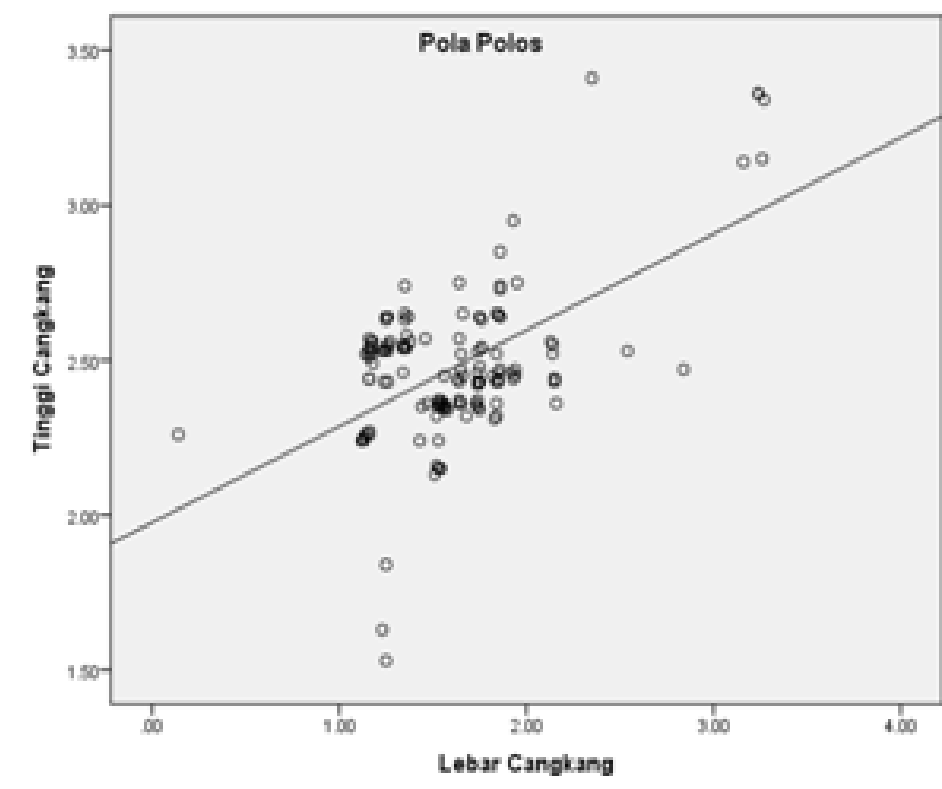

B

Gambar 2. Grafik analisis regresi antara tinggi dan lebar cangkang keong mas $\mathrm{A}=$ cangkang pola garis, $\mathrm{B}=$ cangkang polos

Gambar 2A menunjukkan bahwa sebaran data tinggi dan lebar cangkang keong mas pola garis berada di sekitar garis regresi $\mathrm{Y}=1.890+0.352 \mathrm{X}$ (di mana $\mathrm{Y}$ adalah tinggi cangkang dan $\mathrm{X}$ adalah lebar cangkang). Hal ini berarti setiap kenaikan $1 \mathrm{~cm}$ lebar cangkang akan mengakibatkan kenaikan

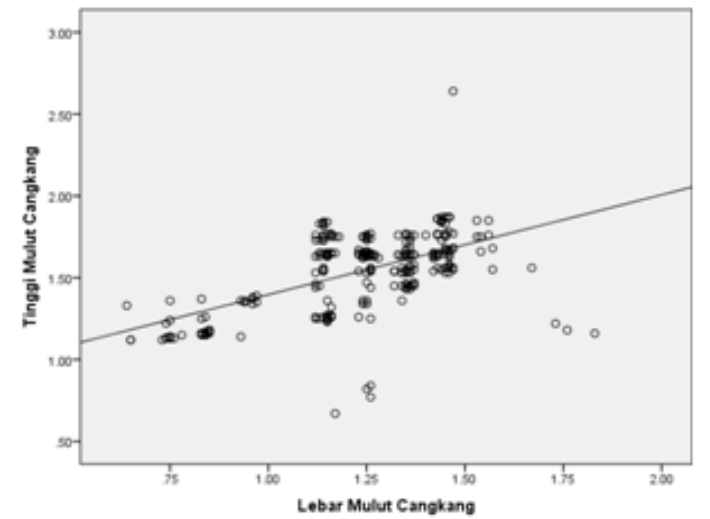

A
$0.352 \mathrm{~cm}$ tinggi cangkang. Gambar 2B menunjukkan bahwa sebaran data tinggi cangkang dan lebar cangkang keong mas pola polos berada di sekitar garis regresi $\mathrm{Y}=1.976+0.310 \mathrm{X}$. Hal ini berarti setiap kenaikan $1 \mathrm{~cm}$ lebar cangkang akan mengakibatkan kenaikan $0.310 \mathrm{~cm}$ tinggi cangkang.

Gambar 3. Grafik analisis regresi antara tinggi dan lebar mulut cangkang keong mas $\mathrm{A}=$ cangkang pola garis, $\mathrm{B}=$ cangkang polos

Gambar 3A menunjukkan bahwa sebaran data tinggi mulut cangkang dan lebar mulut cangkang keong mas pola garis berada di sekitar garis regresi $\mathrm{Y}=0.786+0.610 \mathrm{X}$ (di mana $\mathrm{Y}$ adalah tinggi mulut cangkang dan $\mathrm{X}$ adalah lebar mulut cangkang). Hal ini berarti setiap kenaikan $1 \mathrm{~cm}$ lebar mulut cangkang akan mengakibatkan kenaikan $0.610 \mathrm{~cm}$ tinggi mulut cangkang. Gambar 3B menunjukkan bahwa sebaran data tinggi mulut cangkang dan lebar mulut cangkang keong mas pola polos berada di sekitar garis regresi $\mathrm{Y}=0.806+0.605 \mathrm{X}$. Hal ini berarti setiapkenaikan $1 \mathrm{~cm}$ lebar mulut cangkang akan mengakibatkan kenaikan $0.610 \mathrm{~cm}$ tinggi mulut cangkang.

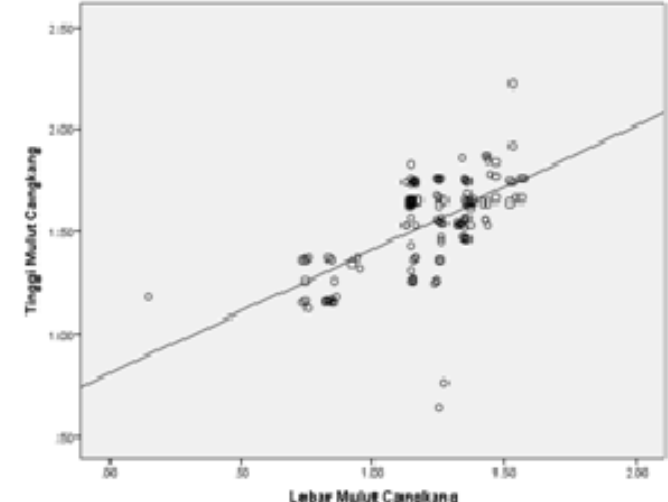

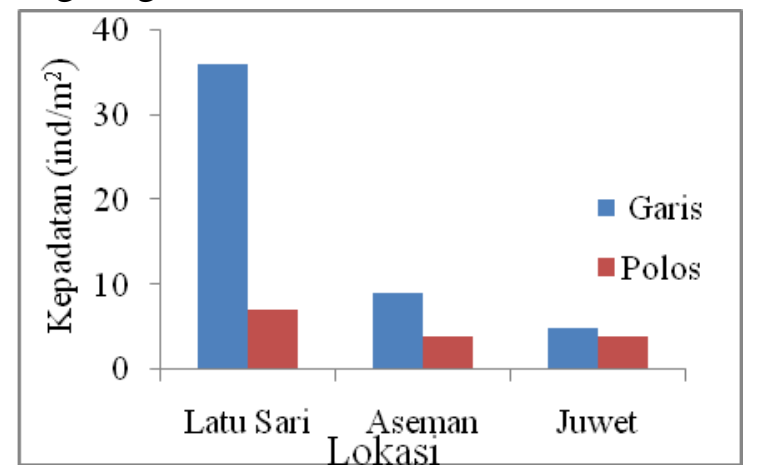

Gambar 4. Rata-rata kepadatan keong mas di ketiga lokasi

\section{PEMBAHASAN}

Keong mas pada penelitian ini ditemukan dua variasi pola warna cangkang yang berbeda yaitu cangkang dengan pola garis dan cangkang polos. Mengacu pada Isnaningsih dan Marwoto (2011), keong mas dengan dua
Kepadatan kedua keong mas tersebut juga bervariasi, kepadatan keong mas dengan pola garis tertinggi ditemukan di persawahan Banjar Latu Sari dengan rata-rata 36 ind $/ \mathrm{m}^{2}$ dan terendah di Banjar Juwet dengan kepadatan $5^{\text {ind }} / \mathrm{m}^{2}$. Untuk keong mas dengan cangkang polos, rata-rata tertinggi ditemukan di Banjar Latu Sari yaitu 7 ind $/ \mathrm{m}^{2}$ dan rata-rata terendah ditemukan di Banjar Aseman dan Juwet dengan kepadatan masing - masing $4 \mathrm{ind} / \mathrm{m}^{2}$ seperti tercantum pada Gambar 2. 
dilaporkan oleh Marwoto dan Isnaningsih (2011), dari beberapa lokasi lainnya yaitu sampel dari wilayah Bengkulu, Palu, Madiun, Bone, Bantimurung dan Danau maninjau. Kisaran hasil pengukuran cangkang keong mas untuk kedua variasi cangkang dari ketiga lokasi penelitian adalah tinggi cangkang $1,53-3,36 \mathrm{~cm}$, lebar cangkang 0,14 $-3,41 \mathrm{~cm}$, tinggi body whorl $1,17-2,83 \mathrm{~cm}$, tinggi mulut cangkang (aperture) $0,64-2,22 \mathrm{~cm}$, lebar mulut cangkang (aperture) $0,15-2,93 \mathrm{~cm}$, sedangkan hasil pengukuran beberapa sampel keong mas yang dilakukan oleh Marwoto dan Isnaningsih (2011), adalah tinggi cangkang 1,258 $6,966 \mathrm{~cm}$, lebar cangkang $0,494-6,490 \mathrm{~cm}$, tinggi body whorl $1,120-6,120 \mathrm{~cm}$, tinggi mulut cangkang (aperture) $0,858-4,97 \mathrm{~cm}$, lebar mulut cangkang (aperture) 0,65$3,431 \mathrm{~cm}$. Kisaran cangkang yang lebih kecil di lokasi penelitian diduga karena sampel keong mas yang terkoleksi umurnya berbeda dengan sampel Marwoto dan Isnaningsih (2011) atau kemungkinan dipengaruhi oleh faktor lingkungan salah satunya adalah ketersediaan pakan. Menurut Cazzaniga (2006) ukuran cangkang diduga sangat dipengaruhi oleh habitat ketersediaan pakan dan predator. Keong yang hidup di lingkungan dengan kandungan bahan organik tinggi biasanya mempunyai ukuran cangkang yang lebih besar dibandingkan dengan keong yang hidup di habitat dengan kandungan bahan organik rendah.

Hasil regresi antar karakter tinggi cangkang dan lebar cangkang kedua variasi cangkang keong mas menunjukkan bahwa tiap kenaikan $1 \mathrm{~cm}$ ukuran lebar cangkang diikuti dengan kenaikan ukuran tinggi cangkang sebesar $0,3 \mathrm{~cm}$ sehingga hal tersebut dapat menunjukkan bahwa bentuk dari cangkang keong mas baik pola garis dan polos adalah cendrung membulat. Hal tersebut sesuai dengan hasil yang dilaporkan oleh Marwoto dan Isnaningsih (2011) yaitu bentuk cangkang keong mas adalah membulat (globuse). Hal yang sama juga ditunjukkan dari hasil regresi antar karakter tinggi mulut cangkang (aperture) dan lebar mulut cangkang (aperture) untuk kedua variasi cangkang keong mas yaitu bahwa tiap kenaikan $1 \mathrm{~cm}$ ukuran lebar mulut cangkang (aperture) diikuti dengan kenaikan ukuran tinggi mulut cangkang (aperture) sebesar $0,6 \mathrm{~cm}$ sehingga hal tersebut dapat menunjukkan bahwa bentuk dari mulut cangkang (aperture) cangkang keong mas baik pola garis dan polos adalah juga cendrung membulat.

Keong mas yang paling banyak ditemukan di masing-masing lokasi adalah keong mas dengan pola garis. Penelitian tentang kepadatan untuk masing-masing variasi keong mas tersebut belum pernah dilaporkan. Tetapi kalau dilihat secara umum kepadatan keong mas yang ditemukan pada sawah di Abiansemal cukup tinggi. Hal tersebut berkaitan dengan faktor lingkungan tempat hidupnya. Dikaitkan dengan umur tanaman padi maka hal tersebut sangat mendukung untuk kehidupan keong mas ditempat penelitian dimana umur tanaman padi masih muda yaitu 20-48 hari sehingga menjadi sumber makanan yang baik bagi keong mas karena batang tanaman padi tidak terlalu keras. Suharto dan Kurniawati (2002) menyatakan bahwa keong mas merupakan hewan nokturnal yangsangat rakus, terutama pada malam hari dan memakan hampir semua tumbuhan dalam air yang masih lunak. Carlsson (2006) menyatakan, keong mas merupakan hama utama di Aceh, yang sering terdapat pada areal sawah beririgasi. Serangan hama dapat sering dialami pada persemaian hingga tanaman berumur dibawah empat minggu setelah tanam.
Gangguan keong mas terjadi pada tanaman padi yang masih muda, sehingga dapat mengurangi kualitas produktif bibit tanaman padi. Keong mas maupun telur keong mas berada pada daerah yang mempunyai kelembaban yang tinggi atau berada di sawah, yang terendam air dalam jangka waktu yang lama (Syam dan Wurjandari, 2005).

Kepadatan keong mas untuk semua variasi cangkang, paling banyak ditemukan di banjar Latu Sari, hal tersebut diduga berkaitan juga dengan umur tanaman padi dimana umur tanaman padi di lokasi tersebut adalah yang paling muda yaitu 21 hari. Hal tersebut tentunya sangat berpengaruh terhadap kehadiran keong mas karena tanaman padi yang masih muda menjadi sumber makanan yang lebih baik dibandingkan yang lebih tua. Menurut Isnaningsih dan Marwoto (2011), keong mas pada umumnya lebih memilih untuk memangsa padi yang berusia muda karena tangkai padi yang lebih lunak. Sedangkan di lokasi lainnya, keong mas yang ditemukan lebih sedikit karena umur tanaman pasi di lokasi tersebut lebih tua dibandingkan dengan di Latu Sari, selain itu di Aseman juga ada kebiasaan petani memungut keong mas yang ada di areal persawahan mereka dan dibuang karena dianggap hama atau merugikan.

Keong mas mampu bertahan hidup didalam tanah hingga sampai 6 bulan lamanya dan bila mendapat suatu pengairan maka keong akan berkembangbiak kembali. Keong mas muda menyerang ruas-ruas tanaman padi yang masih muda (umur $\pm 1-2$ bulan) dan membuat ruas-ruas tanaman patah berserakan di sekitar rumpun tanaman padi. Dampak terburuk adalah produktivitas sawah semakin menurun, bahkan gagal panen (IRRI, 2003). Populasi keong mas yang tinggi dapat merusak tanaman padi hingga sampai 100\% (Hamidy dkk., 2004; Sery dkk., 2006; dan Syahpriansyah dkk., 2009).

Ditinjau dari suhu air pada sawah-sawah tempat penelitian masih berada pada rentang suhu yang diperlukan untuk kehidupan keong mas yaitu $28,3^{\circ} \mathrm{C}-28,6^{\circ} \mathrm{C}$ dimana menurut Halimah dan Ismail (1989), keong mas dapat hidup pada suhu berkisar antara $23{ }^{\circ} \mathrm{C}-32{ }^{\circ} \mathrm{C}$.

Tipe substrat yang berlumpur juga mendukung ditemukannya keong mas dalam jumlah cukup banyak karena keong mas umumnya menyukai habitat dengan substrat berlumpur yang biasanya dijumpai di areal-areal persawahan. Martin et al. (2001) menyatakan bahwa keong mas, $P$. canaliculata memiliki toleransi yang paling tinggi terhadap variasi habitat. Umumnya keong jenis ini menyukai hidup di perairan dangkal dan bersubstrat lumpur.

\section{KESIMPULAN}

Berdasarkan hasil dan pembahasan diatas, dapat disimpulkan bahwa Keong mas yang ditemukan adalah jenis Pomacea canaliculata dengan dua pola warna cangkang yang berbeda yaitu pola garis dan polos. Keong mas yang paling banyak ditemukan di masing-masing lokasi adalah keong mas dengan pola garis. Kepadatan keong mas dengan pola garis tertinggi ditemukan di persawahan Latu Sari $\left(36 \mathrm{ind} / \mathrm{m}^{2}\right)$ dan paling sedikit di banjar Juwet $\left(5 \mathrm{ind} / \mathrm{m}^{2}\right)$ hal yang sama juga ditemukan untuk keong mas pola polos yaitu terbanyak di banjar Latu Sari $\left(7^{\mathrm{ind}} / \mathrm{m}^{2}\right)$ dan paling sedikit di banjar Juwet (4 ind $/ \mathrm{m}^{2}$ ). 


\section{UCAPAN TERIMAKASIH}

Penulis mengucapkan terima kasih Ida Sang Hyang Widhi Wasa, keluarga yang telah memberikan bantuan selama proses penelitian berlangsung dan kepada pembimbing dan penguji

\section{DAFTAR PUSTAKA}

Ameliawati, M. A. 2013. Kandungan Mineral Makro, Mikro dan Total Karatenonoid Telur Keong Mas (Pomacea canaliculata L.) dari Kolam Budidaya FPIK IPB. Skripsi. Institut Pertanian Bogor (IPB). Bogor.

Budiyono, S. 2006. Teknik Mengendalikan Keong Mas pada Tanaman Padi. Jurnal Ilmu-Ilmu Pertanian 2 (2): 128-133.

Carlsson, N. O. L., 2006. "Invasive Golden Apple Snails are Threatening Natural Ecosystems in Southeast Asia." In Joshi. R.C. and L.S. Sebastian (Ed.) Global Advances in Ecology and Management of Golden Apple Snail. PhilRice, Ingnieria DICTUC and FAO.

Carlsson, N. O. L., 2006. "Invasive Golden Apple Snails are Threatening Natural Ecosystems in Southeast Asia." In Joshi. R.C. and L.S. Sebastian (Ed.) Global Advances in Ecology and Management of Golden Apple Snail. PhilRice, Ingnieria DICTUC and FAO.

Cazzaniga, N. J. 2006. Pomacea canaliculata: Harmless and Useless in its Natural Realm (Argentina). In: Global Advances in Ecology and Management of Golden Apple Snails, 37-60. RC Joshi and LS Sebastian (Eds). PhilRice. Philippines.

Cowie RH, KA Hayes and SC Thiengo. 2006. What are apple snails? Confused taxonomy and some preliminary resolution. Inj. Global Advances in Ecology and Management of Golden Apple Snails,323. RC Joshi and LS Sebastian (Eds), PhilRice. Philippines.

Dharma, B. 1992. Siput dan Kerang Indonesia II. Sarana Graha Jakarta.

Direktorat Perlindungan Tanaman Pangan. 2008. Luas Serangan Siput Murbai pada Tanaman Padi Tahun 1997-2006, Rerata 10 Tahun dan Tahun 2007. Direktorat Jenderal Tanaman Pangan, Jakarta.

Hamidy, S., Khalid, J., Adil, M. dan Hamdani, 2004. Rakitan Teknologi Pengendalian Keong Mas. Malang: UMM Press.

Halimah S.W dan Ismail. 1989. Penelitian Pendahuluan Budidaya Siput Emas (Pomacea sp.) Buletin Penelitian Perikanan Darat. Vol.8 No.1. Balai penelitian Perikanan Air Tawar. Bogor.

Isnaningsih, N. R. dan R. M. Marwoto. 2011. Keong Hama Pomacea di Indonesia: Karakter Morfologi dan Sebarannya (Mollusca, Gastropoda: Ampullariidae) [Snail Pest of Pomacea In Indonesia]: Morphology and its Distribution yang telah memberikan kritik dan saran, serta sahabat-sahabat yang membantu penelitian ini berlangsung dari awal hingga akhir.

(Mollusca, Gastropoda: Ampullariidae)]. Berita Biologi 10(4): 441-447

Martin P.R., A.L Estebenet and N.J Cazzaniga. 2001. Factors affecting the distribution of Pomacea canaliculata (Gastropoda: Ampullariidae) along its southernmost natural limit. Malacologia 43(1-2), 12-23.

Marwoto, R.M. dan N. R. Isnaningsih. 2011.Notes on the Distribution ofInvasive Freshwater Snail (Lamarck, 1822) and (D'orbigny, 1835) In IndonesiaPomacea canaliculate, $P$. Insularum. Biotropia Vol. 18 No. 2, 2011: 123 - 128

Nontji, A. 2002. Laut Nusantara. Djambatan Jakarta.

Ramakrishna, S., R. Alexander, P. Deepak and M. Jayashankar. 2014. Intraspecific Variation in Shell Morphometry of Bellamya dissimilis (Mueller, 1774) (Architaenioglossa: Viviparidae) from three different lakes of Bangalore Urban District. Int. J. of Pharm. Life Sci. 5 (5).3540-3545.

Sery, R.A., Sunarsi; dan Idris, 2006. Pengelola Keong Mas (Pomacea canaliculata) untuk mengendalikan Gulma pada Tanaman Padi Sawah.

Suharto, H. dan N. Kurniawati. 2002. Keong mas, dari Hewanpeliharaan menjadi Hama Utama Padi Sawah. Balai Besar Penelitian Tanaman Padi: 385- 403

Suharto, H. R. M. Marwoto, Heryanto, Mulyadi and SSSiwi.2006. The Golden Apple Snail, Pomacea spp. in Indonesia, lnj. Global Advances in Ecology and Management of Golden Apple Snails23\-242, RC Joshi and LS Sebastian (Eds). PhilRice, Philippines.

Syahpiansyah, N., Wibowo, L., dan Indryati. 2009. Pengaruh Eksrak Kasar Buah palem Ekor Tupai (Wodyetia bifurcata W) Terhadap Mortalitas Keong Mas (Pomacea sp.) di Rumah Kaca.

Syam, M. dan D. Wujandari. 2005. Masalah Lapang (Hama, Penyakit dan Hara) pada Padi. Jakarta: Kerjasama Balai Penelitian Tanaman Padi, BP2TP, BPTP dan IRRI

Wiresyamsi, A. dan H. Haryanto. 2008. Pengendalian Hama Keong Mas (Pomacea canaliculata L.) dengan Teknik Perangkap dan JebakanPest Control of Golden Snail (Pomacea canaliculata L.) by Application of Attractant and Trapping Techniques.CropAgro, Vol 1:137-143 